\title{
Performance evaluation of hybrid modified micro-channel solar cell thermal tile: an experimental validation
}

\author{
Sanjay Agrawal ${ }^{1 *}$, G.N. Tiwari ${ }^{1}$ \\ Centre for Energy Studies, Indian Institute of Technology Delhi, New Delhi, INDIA \\ *Corresponding Author: e-mail: sanju.aggrawal@gmail.com, Tel +91-9911428863, Fax.+91-11-26591251
}

\begin{abstract}
In this communication, an attempt has been made to evaluate the performance of hybrid modified micro-channel solar cell thermal (MCSCT) tile. Based on energy balance of each component of modified MCSCT tile, analytical expressions for the different parameters of modified MCSCT tiles connected in series have been derived. An attempt has also been made to validate the thermal model with experimental results of prototype of modified micro-channel solar cell thermal tile in indoor condition for New Delhi. An indoor test setup and modified micro-channel solar cell thermal (MCSCT) tile has been developed for experimental purpose. Performance evaluation of modified micro-channel solar cell thermal tile over different intensities has been studied. It has been observed that the thermal and electrical efficiency of the modified micro-channel solar cell thermal tile are $35.7 \%$ and $12.4 \%$, respectively. On the basis of numerical computation, overall energy and exergy analysis have also been carried out.
\end{abstract}

Keywords: Solar cell thermal tile, Micro-channel, Electrical efficiency, Thermal modeling.

\section{Introduction}

The temperature of solar cell is increased by the absorbed solar radiation that is not converted into electricity, causing a decrease in their electrical efficiency. For mono crystalline (c-Si) and polycrystalline (pc-Si) silicon solar cells, the efficiency decreases by about $0.45 \%$ for every degree rise in temperature. For amorphous silicon (a-Si) cells, the effect is less, with a decrease of about $0.25 \%$ per degree rise in temperature depending on the solar cell design. This undesirable effect can be partially avoided by a proper heat extraction with a fluid circulation. In hybrid photovoltaic thermal (PVT) solar systems, the reduction of PV module temperature can be combined with useful fluid heating. Therefore, hybrid PVT systems can simultaneously provide electrical and thermal energy, achieving a higher energy conversion rate of the absorbed solar radiation. These systems consist of PV modules coupled to heat extraction devices in which air or water of lower temperature than that of the PV modules is heated, while at the same time, the PV module temperature is reduced. In PVT system applications, the production of electricity is the main priority, and therefore, it is necessary to operate the PV modules at low temperature in order to keep the solar cell electrical efficiency at a sufficient level. PVT systems provide a higher energy output than standard PV modules and could be cost effective if the additional cost of the thermal unit is low. Several designs of hybrid PVT solar air heater had been proposed in the past. Among the first, Kern and Russel (1978) have given the main concept of photovoltaic thermal collector using water or air as the working fluid and they found that the hybrid collector system are attractive in small buildings that have substantial heating loads. Cox and Raghuraman (1985) have studied air type hybrid PVT system and made use of computer simulation to optimize the design of flat plate PVT solar air collector in order to increase the solar absorption and reducing the infrared emittance. Bhargava et al. (1991) and Prakash (1994) have studied the effect of air mass flow rate, air channel depth, length and fraction of absorber plate area covered by solar cells on single pass air heater. They concluded that the solar cell efficiency was marginally improved while an average thermal efficiency of about $50-70 \%$ for water heating and $17-51 \%$ for air heating was obtained. Garg et al. (1994) have done experimental study on a hybrid photovoltaic thermal solar water heater and they found that the thermal and electrical efficiencies of the hybrid solar water heater are 33.5 and $3.35 \%$, respectively.

A double pass photovoltaic thermal solar collector for solar drying applications has been developed and tested by Sopian et al. (2000) and they concluded that both thermal and electrical energies are produced simultaneously and in addition, the packing factor or the area fraction covered by photovoltaic cells can be adjusted according to the requirement for electrical energy. Garg and Adhikari (1997) developed a computer simulation model for predicting the transient performance of PVT air 
heating collector with single and double glass configurations and they concluded that that the system efficiency increases with increase in collector length, mass flow rate and cell density, and decreases with increase in duct depth for both configurations. An extensive investigation of the thermal, electrical, hydraulic and overall performances of flat plate photovoltaic thermal (PVT) air collectors has been made by Hagazy (2000) and it has been observed that the flow channel (depth of channel/length of channel) ratio is an important design parameter which influence the performance of PVT air collectors. Kalogirou (2001) has carried out monthly performance of an unglazed hybrid PVT system under forced mode of operation for climatic condition of Cyprus and it has been found that the hybrid system increases the mean annual efficiency of the PV solar system from $2.8 \%$ to $7.7 \%$ and in addition covers $49 \%$ of the hot water needs of a house, thus increasing the mean annual efficiency of the system to $31.7 \%$.

Thermal modeling of building integrated photovoltaic system has been presented by Lee et al.(2001) and they have given interesting modeling results on air cooled PV modules. Tiwari et al. (2006) have validated the theoretical and experimental results for photovoltaic (PV) module integrated with air duct for composite climate of India and they concluded that an overall thermal efficiency of PVT system is significantly increased due to utilization of thermal energy from PV module. Annual performance of building integrated photovoltaic water -heating system for Hongkong climate has been presented by chow et al.(2003) and they have observed that annual thermal and cell conversion efficiencies are 37.5\% and 9.39\%, respectively. An experimental study on energy generation with a photovoltaic (PV) solar thermal hybrid system has been done Erdil et al. (2008) and they concluded that the loss in the electrical energy generation is well offset by a large gain, $Q_{w}$, in thermal energy that is collected by the circulating water. Chow (2010) has reviewed the trend of development of the hybrid photovoltaic thermal solar technology, in particular the advancements in recent years and the future work required.

Energy and exergy analysis of photovoltaic-thermal collector with and without glass cover has been discussed by Chow et al. (2009) and they concluded that from the first law point of view, a glazed PVT system is found always suitable if we are to maximize the quantity of either the thermal or the overall energy output. From the exergy analysis point of view however, the increase of PV cell efficiency, packing factor, water mass to collector area ratio, and wind velocity are found favorable to go for an unglazed system, whereas the increase of on-site solar radiation and ambient temperature are favorable for a glazed system. Nayak and Tiwari (2008) have made exergy analysis of integrated photovoltaic thermal (IPVT) water heater under constant flow rate and they observed that an overall exergy and thermal efficiency of IPVT is maximum at the hot water withdrawal flow rate of $0.006 \mathrm{~kg} / \mathrm{s}$. Exergy analysis of integrated photovoltaic thermal solar (IPVTS) water heater under constant flow rate and constant collection temperature modes has been done by Tiwari et al. (2009) and they observed that the daily overall thermal efficiency of IPVTS system increases with increase constant flow rate and decrease with increase of constant collection temperature. Performance analysis of a hybrid photovoltaic-thermal integrated system has also been done by Radziemska (2009) who presented the concept of exergy analysis for evaluation of the PVT systems which is very useful tools for the improvement and cost-effectiveness of the system. The performance in terms of overall annual thermal, exergy gain and exergy efficiency of proposed micro-channel photovoltaic thermal module have been evaluated by Agrawal and Tiwari (2011) and they concluded that proposed hybrid micro-channel photovoltaic thermal module gives better results than single channel photovoltaic thermal module of Dubey et al. (2006) .

The main objective of this paper is to study on single modified solar cell thermal tile having micro-channel to see the effect of intensity on overall performance of modified micro-channel solar cell thermal tile because till now large area of channel or duct based photovoltaic thermal system has been found in literature. An attempt has been done to design modified microchannel solar cell thermal tile with experimental setup and its performance over different intensity in indoor conditions have been examined.

\section{Experimental setup}

\subsection{Modified Micro-channel solar cell thermal tile:}

The present study has been carried out on single modified micro-channel solar cell thermal (MCSCT) tile. The MCSCT tile consists of a single solar cell (mono crystalline silicon), rated at $2.2 \mathrm{Wp}$ having dimensions $0.12 \mathrm{~m}$ length and $0.12 \mathrm{~m}$ width has been considered and it has been mounted on a rectangular wooden channel. The channel has dimensions $0.12 \mathrm{~m}$ length, $0.12 \mathrm{~m}$ width and $5000 \mu \mathrm{m}$ depth. The wooden channel has been sealed with putty and adhesive tape to avoid air leakage. There is provision of inlet and outlet air to flow through the micro-channel. Air flow pattern of modified micro-channel solar cell thermal tile has been shown in Figure. 1(a). The MCSCT tile has been placed on a mild steel platform of solar simulator with a mechanism for up and down movement for varying the light intensity. A DC fan of $6.0 \mathrm{~V}$ and $0.1 \mathrm{~A}$ has been used to circulation of the air through the channel. 


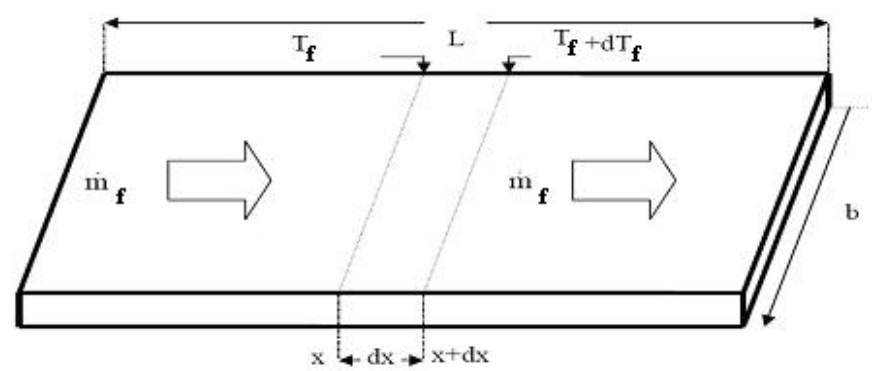

Figure. 1(a). Air flow pattern over elementary area $b d x$ of modified micro-channel solar cell thermal (MCSCT).

\subsection{Solar simulator}

A solar simulator (Figure. 1(b) )with a 3-phase lamp array is employed to imitate the necessary solar irradiation in the testing of micro-channel solar cell thermal tile. The solar simulator has 28 tungsten halogen lamps (Philips manufactured; Model: 392472 ) each having 500W, 9000 lumens and rated at $240 \mathrm{~V}$ and $11 \mathrm{~A}$. The halogen lamps are arranged in $7 \times 4$ matrices for uniform distribution of irradiance on the MCSCT tile.

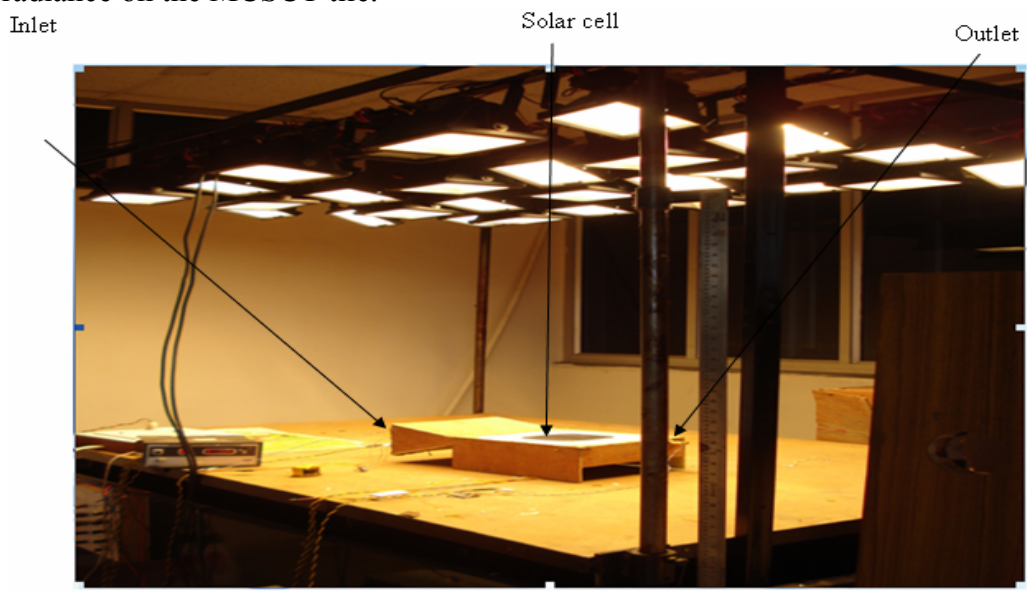

Figure.1(b) Photograph of solar simulator with micro-channel solar cell thermal (MCSCT) tile

The available area for testing is $1 \times 2 \mathrm{~m}$. The height of the simulator from the floor is $200 \mathrm{~cm}$. The distance between platform and halogen lamp is $100 \mathrm{~cm}$. Intensity of simulator can be varied between $300 \mathrm{~W} / \mathrm{m}^{2}$ to $1000 \mathrm{~W} / \mathrm{m}^{2}$ by decreasing the gap of solar simulator (halogen lamp) and platform.

\subsection{Instrumentation}

(i)Thermocouples: Calibrated copper-constantan thermocouples and digital temperature indicator are used to measure the temperature at several locations, namely, back surface, inlet and outlet points of each collector and final outlet point. Digital temperature indicator has a least count of $0.1{ }^{\circ} \mathrm{C}$.

(ii) Solarimeter: The intensity of solar radiation is measured by solarimeter having a least count of $20 \mathrm{~W} / \mathrm{m}^{2}$, manufactured by CEL, India Ltd, Sahibabad (UP), India. Solarimeter has been calibrated with standard pyranometer.

(iii) Anemometer (Lutron-AM4201): It is conventional instrument used to measure the velocity of flowing air. The least count of instrument is $0.1 \mathrm{~m} / \mathrm{s}$.

(iv) Infrared thermometer: The infrared thermometer is used to measure top surface temperature of modified micro-channel solar cell thermal tile. Least count of the instrument is $0.1^{\circ} \mathrm{C}$.

(v) Clamp meter: It is used for measurement of current and voltage. Least count of the instrument is $0.1 \mathrm{~A}$ and $0.1 \mathrm{~V}$ respectively.

\section{Thermal modeling of modified micro-channel solar cell thermal tile}

To write the energy balance equation of modified micro-channel solar cell thermal (MCSCT) tile, the following assumptions have been made:

*One dimensional heat-conduction is good approximation for present study.

*There is no temperature gradient along the thickness of MCSCT tile. 
*The specific heat of air remains constant. It does not change with rise in temperature of air.

*The system is in quasi-steady state.

*The ohmic losses in the MCSCT tile are negligible.

*There is stream line flow of air through the micro-channel at small flow rate.

Following Agrawal and Tiwari (2011) \& Tiwari and Sodha (2006), the energy balance equation for modified MCSCT tile can be written as

$\left[\alpha_{c} \tau_{g} I(t) b d x\right]=\left[U_{t c a}\left(T_{c}-T_{a}\right) b d x+U_{t c f}\left(T_{c}-T_{f}\right) b d x\right]+\tau_{g} \eta_{c} I(t) b d x$

$\left[\begin{array}{l}\text { Rate of solar } \\ \text { energy available } \\ \text { on solar cell }\end{array}\right]=\left[\begin{array}{l}\text { Rate of heat loss from } \\ \text { top surface of solar cell } \\ \text { to ambient }\end{array}\right]+\left[\begin{array}{l}\text { Rate of heat transfer } \\ \text { from solar cell to } \\ \text { flowing fluid i.e. air }\end{array}\right]+\left[\begin{array}{l}\text { Rate of } \\ \text { electrical energy } \\ \text { produced }\end{array}\right]$

From Equation (1), the expression for cell temperature is

$$
T_{c}=\frac{\tau_{g} \alpha_{c} I(t)-\tau_{g} \eta_{c} I(t)+U_{t c a} T_{a}+U_{t c f} T_{f}}{U_{t c a}+U_{t c f}}
$$

or

$$
T_{c}=\frac{\alpha_{e f f} I(t)+U_{t c a} T_{a}+U_{t c f} T_{f}}{U_{t c a}+U_{t c f}}
$$

where $\alpha_{e f f}=\tau_{g}\left(\alpha_{c}-\eta_{c}\right)$

An expression for temperature dependent electrical efficiency of a MCSCT tile as given by Schott (1985) and Evans (1981) is,

$$
\eta=\eta_{0}\left[1-0.0045\left(\overline{T_{c}}-\overline{T_{a}}\right)\right]
$$

Energy balance for air flowing in the micro-channel of solar cell thermal tile for elemental area $b d x$ is given by

$$
U_{t c}\left(T_{c}-T_{f}\right) b d x=m_{f} C_{f} \frac{d I_{f}}{d x} d x+U_{b}\left(T_{f}-T_{a}\right) b d x
$$

$\left[\begin{array}{l}\text { Rate of heat transfer } \\ \text { from solar cell to } \\ \text { flowing fluid i.e. air }\end{array}\right]=\left[\begin{array}{l}\text { The mass flow } \\ \text { rate of flowing } \\ \text { fluid i.e. air }\end{array}\right]+\left[\begin{array}{l}\text { Rate of heat transfer } \\ \text { from flowing fluid to } \\ \text { ambient }\end{array}\right]$

Solving Equation (2) and Equation (4) with boundary condition at $\mathrm{x}=0, \mathrm{~T}_{\mathrm{f}}=\mathrm{T}_{\mathrm{fi}}$; one gets

$$
T_{f}=\left[\frac{h_{p} \alpha_{e f f}}{U_{L}} I(t)+T_{a}\right]\left[1-\exp \left(\frac{-b U_{L} x}{m_{f} C_{f}}\right)\right]+T_{f i} \exp \left(\frac{-b U_{L} x}{m_{f} C_{f}}\right)
$$

At, $\mathrm{x}=\mathrm{L}, \mathrm{T}_{\mathrm{f}}=\mathrm{T}_{\mathrm{fo}}$, the outlet air temperature of modified micro-channel solar cell thermal tile, is

$$
T_{f o}=\left[\frac{h_{p} \alpha_{\text {eff }}}{U_{L}} I(t)+T_{a}\right]\left[1-\exp \left(\frac{-b U_{L} L}{m_{f} C_{f}}\right)\right]+T_{f i} \exp \left(\frac{-b U_{L} L}{m_{f} C_{f}}\right)
$$

The average air temperature over the length of air channel below micro-channel solar cell thermal tile as obtained with help of Equation. (5) is

$$
\bar{T}_{f}=\frac{1}{L} \int_{0}^{L} T_{f} d x
$$




$$
=\left[\frac{h_{p} \alpha_{\text {eff }}}{U_{L}} I(t)+T_{a}\right]\left[1-\frac{1-\exp \left(\frac{-b U_{L} L}{m_{f} C_{f}}\right)}{\frac{b U_{L} L}{m_{f} C_{f}}}\right]+T_{f i}\left[\frac{1-\exp \left(\frac{-b U_{L} L}{m_{f} C_{f}}\right)}{\frac{b U_{L} L}{m_{f} C_{f}}}\right]
$$

For a number of modified MCSCT tiles connected in series, the outlet temperature of first MCSCT tile will be the inlet for second MCSCT tile, the outlet temperature of second MCSCT tile will be the inlet for the third and so on. Hence, for a system of $\mathrm{N}$ number of MCSCT tiles connected in series, the outlet air temperature from $\mathrm{N}^{\text {th }}$ MCSCT tile can be expressed in terms of first MCSCT tile.

The outlet air temperature of $\mathrm{N}$ number of modified micro-channel solar cell thermal tiles connected in series is derived as

$T_{f \circ N}=\left[\frac{h_{p} \alpha_{e f f}}{U_{L}} I(t)+T_{a}\right]\left[1-\exp \left(\frac{-N b U_{L} L}{m_{f} C_{f}}\right)\right]+T_{f i} \exp \left(\frac{-N b U_{L} L}{m_{f} C_{f}}\right)$

The rate of useful thermal energy obtained for $\mathrm{n}_{\mathrm{pv}}$ row of MCSCT tile connected in series is derived as

$$
\dot{Q}_{U, N}=n_{p v} \times \dot{m}_{f} C_{f}\left(T_{f o N}-T_{f i}\right)
$$

or

$$
\dot{Q}_{U, N}=n_{p v} \times \dot{m}_{f} C_{f}\left[1-\exp \left(\frac{-N b U_{L} L}{\dot{m}_{f} C_{f}}\right)\right]\left[\frac{h_{p} \alpha_{e f f}}{U_{L}} I(t)+T_{a}-T_{f i}\right]
$$

3.1 Instantaneous thermal efficiency

An instantaneous thermal efficiency of hybrid micro-channel solar cell thermal tile can be obtained as, Duffie and Beckman (24) and Tiwari (25),

$$
\begin{aligned}
& \eta_{t h}=\frac{\dot{Q}_{U, N}}{N A_{c} I(t)} \\
& \eta_{t h}=\frac{m_{f} C_{f}}{U_{L} N A_{c}}\left[1-\exp \left(\frac{-N b U_{L} L}{\dot{m}_{f} C_{f}}\right)\right]\left[h_{p} \alpha_{e f f}-U_{L} \frac{\left(T_{f i}-T_{a}\right)}{I(t)}\right]
\end{aligned}
$$

3.2 Electrical efficiency

Experimental efficiency of MCSCT tile can be calculated as

$$
\eta_{e}=\frac{F F \times V_{o c} \times I_{s c}-I_{L} \times V_{L}}{A_{m} \times I(t)}
$$

where fill factor $(\mathrm{FF})$ is measure of sharpness of the $I-V$ curve. It indicates how well a junction was made in the cell and how low is the series resistance. It can be lowered by the presence of series resistance and tends to be higher whenever the open circuit voltage is high.

3.3 Energy Analysis

The energy analysis is based on the first law of thermodynamics, and the expression for overall thermal gain can be defined as,

$\sum \dot{Q}_{u, \text { total }}=\sum \dot{Q}_{u, \text { thermal }}+\frac{\sum \dot{Q}_{u, \text { electrical }}}{\eta_{\text {cpower }}}$

where

$$
\dot{Q}_{u, \text { thermal }}=\frac{\dot{Q}_{u N}}{1000}
$$

Overall thermal gain from a PVT system $=$ Thermal energy collected by the PVT system $+\left(\right.$ Electrical output $\left./ \eta_{\text {cpower }}\right)$. 
where, $\eta_{\text {cpower }}$ is the electric power generation efficiency conversion factor of a conventional power plant for India.

This is so because electrical energy is a high-grade form of energy which is required for operation of DC motor. This electrical energy has been converted to equivalent thermal by using electric power generation efficiency conversion factor as $0.20-0.40$ for a conventional power plant, Huang et al. (26) and it depends on quality of coal. Usual value of this factor is taken as 0.38 for conversion.

\subsection{Exergy Analysis}

. The exergy analysis is based on the second law of thermodynamics, which includes accounting the total exergy inflow, exergy outflow and exergy destructed from the system.

$$
\begin{aligned}
& \dot{E} x_{\text {thermal }}=\dot{Q}_{U, N}\left[1-\frac{T_{a}+273}{T_{f o}+273}\right] \\
& \dot{E} x_{\text {electrical }}=\left[\frac{\eta \times A \times I(t)}{1000}\right] \dot{E} x_{\text {overall }}=\dot{E} x_{\text {thermal }}+\dot{E} x_{\text {electrical }}
\end{aligned}
$$

where, $A$ is area of module and $T_{s}$ is the sun temperature in Kelvin.

\subsection{Statistical analysis}

To compare the theoretical and experimental results, the correlation coefficient (r) and root mean square percent deviation (e) have been evaluated by using the following expression:

$$
r=\frac{N\left(\sum X_{i} \times Y_{i}\right)-\left(\sum X_{i}\right)\left(\sum Y_{i}\right)}{\sqrt{N \sum X_{i}^{2}-\left(\sum X_{i}\right)^{2}} \sqrt{N \sum Y_{i}^{2}-\left(\sum Y_{i}\right)^{2}}}
$$

and $e=\sqrt{\frac{\sum\left(e_{i}\right)^{2}}{N}}$

where $e_{i}=\left[\frac{X_{i}-Y_{i}}{X_{i}}\right] \times 100$

\section{Results and Discussions}

In a series of experiments conducted, data have been recorded for different intensities for comparative evaluation on single modified micro-channel solar cell thermal (MCSCT) tile. Theoretical value of cell temperature of modified MCSCT tile has been computed from equation.(2) using MATLAB 7.0 at solar radiation $\left(700 \mathrm{~W} / \mathrm{m}^{2}\right)$, constant mass flow rate $(0.000145 \mathrm{~kg} / \mathrm{s})$ and $\mathrm{T}_{\mathrm{fi}}=38{ }^{\circ} \mathrm{C}$. The variation of cell temperature with respect to time of single modified MCSCT tile for theoretical and experimental results has been shown in Figure. 2 Figure shows that there is good agreement between theoretical and experimental values. The correlation coefficient and root mean square percentage deviation between theoretical and experimental results are 0.998 and 3.21, respectively. Similarly, equation. (8) has been used for calculating outlet temperature of modified MCSCT tile using MATLAB 7.0 at solar radiation $700 \mathrm{~W} / \mathrm{m}^{2}$ and $\mathrm{T}_{\mathrm{fi}}=38{ }^{0} \mathrm{C}$. The theoretical and experimental results are validated for outlet air temperatures of single modfied MCSCT tile as shown in Figure. 3. The correlation coefficient and root mean square percentage deviation between theoretical and experimental results are 0.995 and 4.37 , respectively.

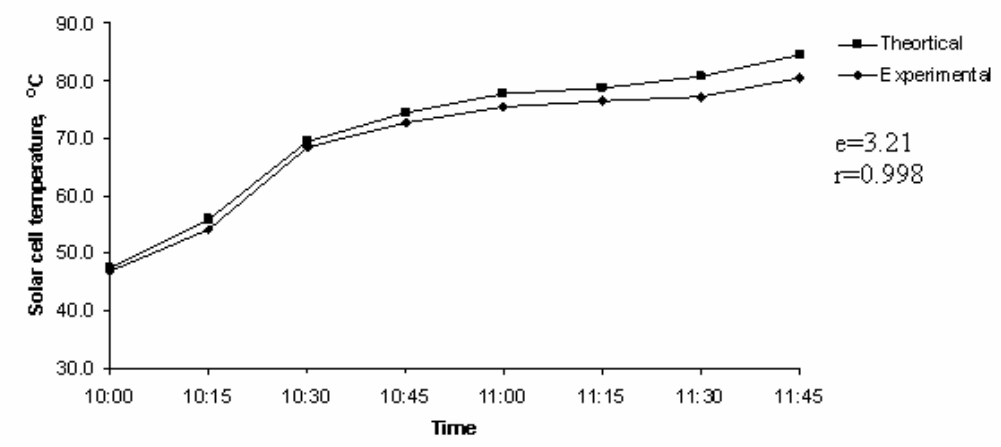

Figure 2. Variation of cell temperature of single MCSCT tile at solar radiation $700 \mathrm{~W} / \mathrm{m}^{2}$ 


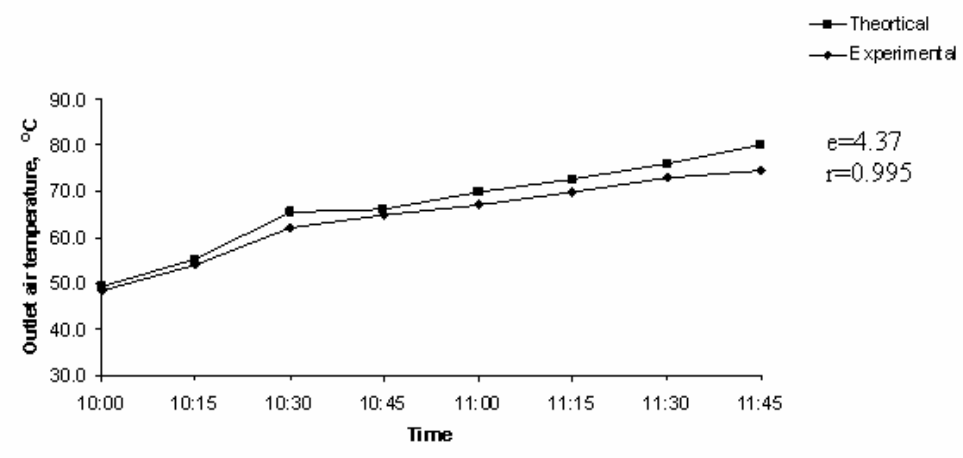

Figure 3. Variation of outlet air temperature of single modified MCSCT tile at solar radiation $700 \mathrm{~W} / \mathrm{m}^{2}$

equation. (3) has been used for calculating the electrical efficiency of MCSCT tile. Figure. 4 shows the time variation of cell temperature and electrical efficiency at different intensities $600 \mathrm{~W} / \mathrm{m}^{2}, 700 \mathrm{~W} / \mathrm{m}^{2}$ and $800 \mathrm{~W} / \mathrm{m}^{2}$ respectively. It has been found that as intensity increases, electrical efficiency decreases because of rise in cell temperature and this result is in accordance with result reported by earlier researchers, Zondag et al.(2002).

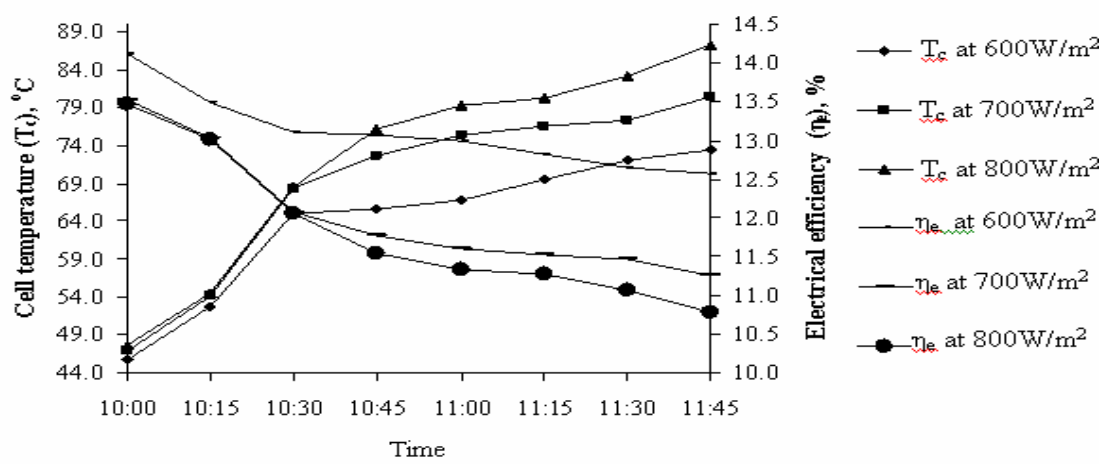

Figure 4. Variation of cell temperature and electrical efficiency of single MCSCT tile at different intensity.

It has also been observed that electrical efficiency for this MCSCT tile in the range of $13.5 \%$ to $11.3 \%$ at $800 \mathrm{~W} / \mathrm{m}^{2}$ .Equation. (9) has been used for calculating rate of thermal gain for MCSCT tile and using this data in equation. (11), thermal efficiency has been calculated .Fig. 5 shows the time variation of outlet temperature and thermal efficiency at different intensities $600 \mathrm{~W} / \mathrm{m}^{2}, 700 \mathrm{~W} / \mathrm{m}^{2}$ and $800 \mathrm{~W} / \mathrm{m}^{2}$ respectively. It has been found that as intensity increases, outlet temperature of MCSCT tile also increases and due to increase in outlet temperature, thermal efficiency is increased because inlet temperature $\mathrm{T}_{\mathrm{fi}}=38{ }^{\circ} \mathrm{C}$ is maintained constant. It has also been observed that as there is increase in duration of time, outlet air temperature also increased and approaches the steady state condition after approximately two hours because of thermal capacity of MCSCT tile. The maximum outlet air temperature $86.6{ }^{\circ} \mathrm{C}$ and thermal efficiency $35.7 \%$ were observed at 800 $\mathrm{W} / \mathrm{m}^{2}$ at steady state for single MCSCT tile.
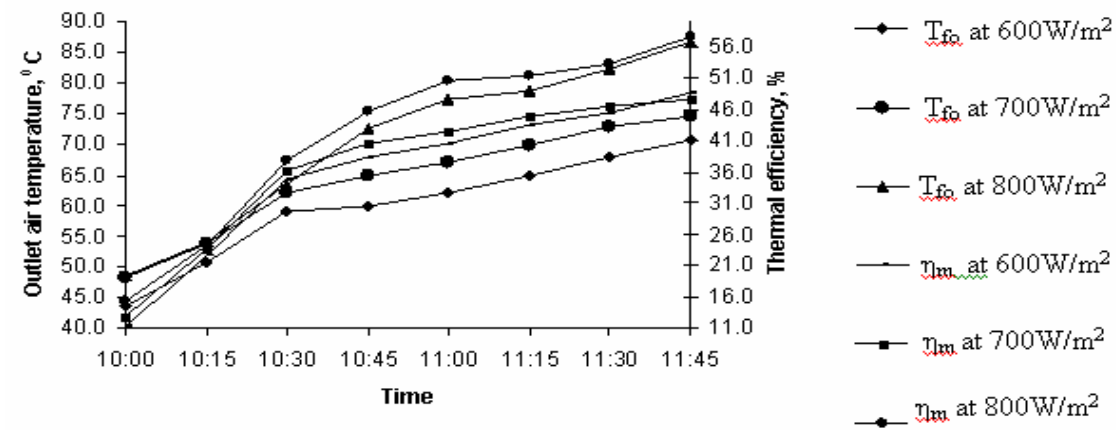

Figure 5. Variation of outlet air and thermal efficiency of single MCSCT tile at different intensity

Figure. 6 shows the time variation of electrical power at different intensities. It has been observed that electrical power decreases as time increases because temperature of MCSCT tile goes on increase as time increase on the basis of this one can conclude that if fan were not installed there were more decrement in electrical power .One interesting result has also been observed that there is decrement in electrical power from $1.61 \mathrm{~W}$ to $1.46 \mathrm{~W}$ at intensity $600 \mathrm{~W} / \mathrm{m}^{2}$ and from $2.16 \mathrm{~W}$ to $1.51 \mathrm{~W}$ at intensity $800 \mathrm{~W} / \mathrm{m}^{2}$ for the same duration i.e. two hour and same mass flow rate. On the basis of this result it is concluded that more electrical power is generated at higher intensity but there is more drop of electrical power with respect to time at 
higher intensity. Hourly variation of thermal gain at various intensities has been shown in Figure. 7. It has been seen that 27.5 $\%$ more thermal gain is achieved at $800 \mathrm{~W} / \mathrm{m}^{2}$ with respect to $600 \mathrm{~W} / \mathrm{m}^{2}$ at steady state. It can be seen that increase in time duration will increase in the thermal output while decrease in the electrical efficiency. Experimental results shows that increase in intensity will increase the thermal output. It has been observed that increase in intensity will increase the overall thermal energy for MCSCT tile.

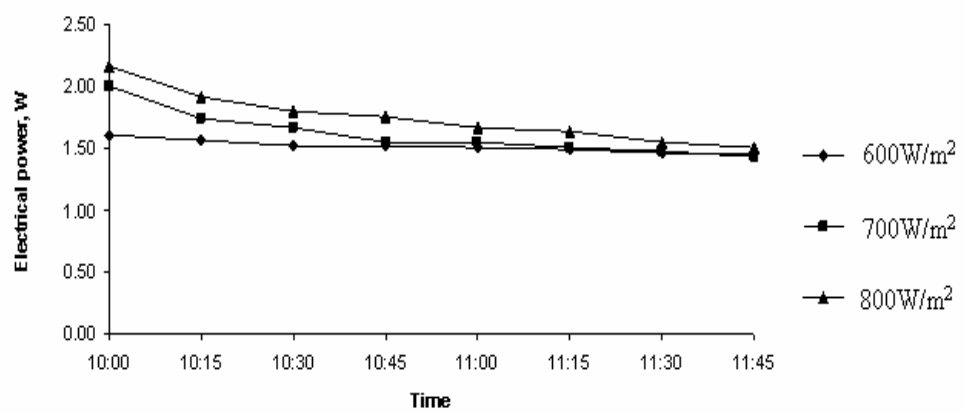

Figure 6. Variation of electrical power of single MCSCT tile at different intensity.

It is seen that $7.3 \%$ more overall thermal energy is achieved when experiment is done at $700 \mathrm{~W} / \mathrm{m}^{2}$ as compare to $600 \mathrm{~W} / \mathrm{m}^{2}$ but when experiment is done at $800 \mathrm{~W} / \mathrm{m}^{2}$ then increment in overall thermal energy is $21.1 \%$ as compare to $700 \mathrm{~W} / \mathrm{m}^{2}$ it is due to more thermal gain is achieved at $800 \mathrm{~W} / \mathrm{m}^{2}$ and electrical power is more unless same at all intensities at steady state. Similarly trends have been experienced for overall exergy for the MCSCT tile as shown in Figure. 9

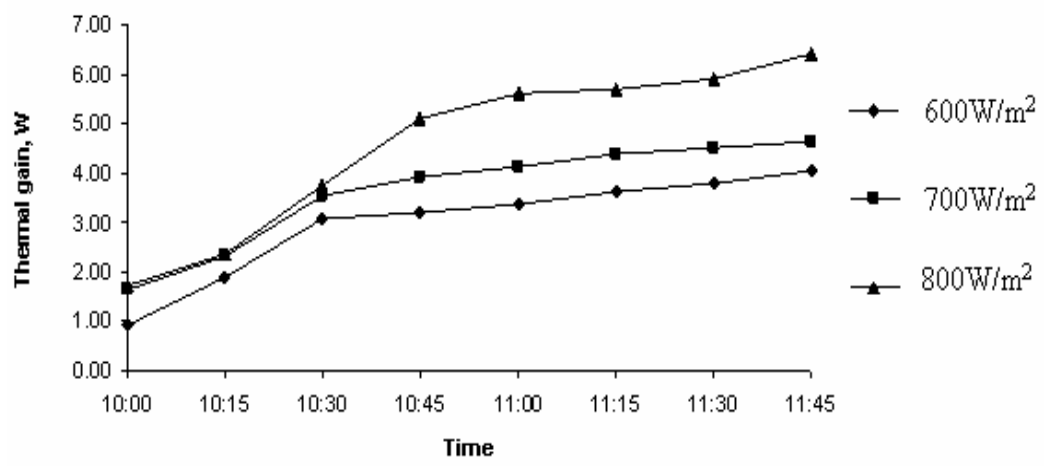

Figure 7. Variation of thermal gain of single MCSCT tile at different intensity.

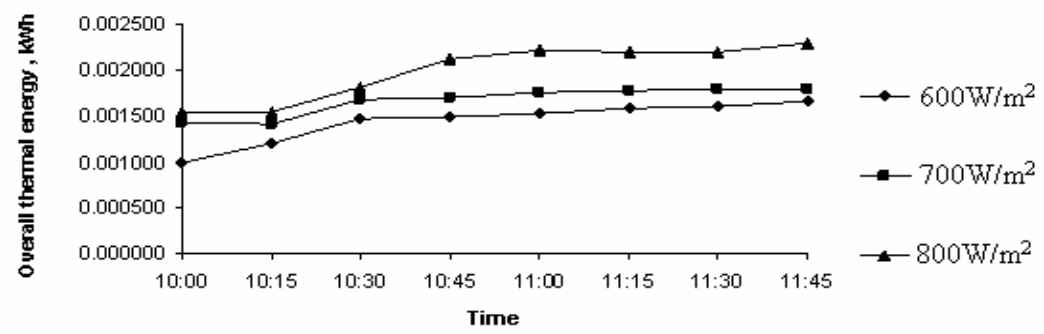

Figure 8. Variation of overall energy of single MCSCT tile at different intensity

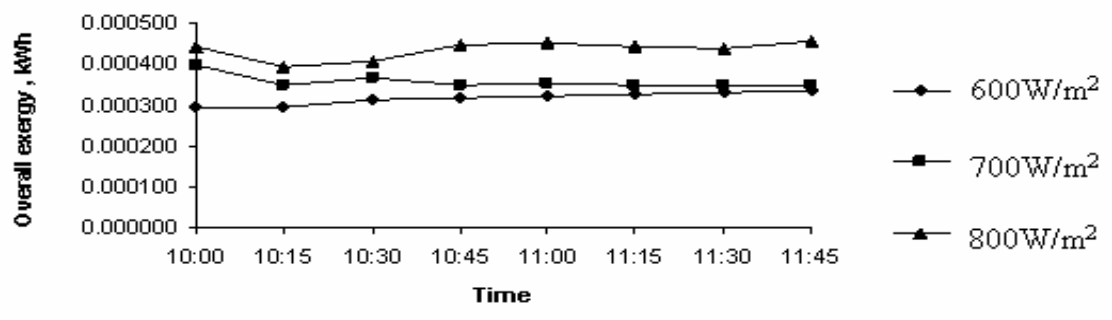

Figure 9. Variation of overall exergy of single MCSCT tile at different intensity 


\section{Conclusions}

The following conclusions have been drawn

- $\quad$ The thermal and electrical efficiency are $35.7 \%$ and $12.4 \%$ respectively for single MCSCT tile.

- This new present setup would have beneficial effect of permitting much less expensive installation for testing and development. Hence the test procedure can be used by manufacturers for testing of different type of PV tiles and combination of PV tiles in order to optimize its products for better efficiency

\section{Nomenclature}

$\mathrm{A}_{\mathrm{c}} \quad$ Area of solar cell, $\mathrm{m}^{2}$

$b$ Width of the micro-channel, $\mathrm{m}$

$C_{f} \quad$ Specific heat of air, $\mathrm{J} / \mathrm{kg} \mathrm{K}$

$d x \quad$ Elemental length, $\mathrm{m}$

dt Elemental time, sec

$h$ Heat transfer coefficient, $\mathrm{W} / \mathrm{m}^{2} \mathrm{~K}$

$h_{b i}$ Heat transfer coefficient from back of tedlar to ambient, $\mathrm{W} / \mathrm{m}^{2} \mathrm{~K}$

$h_{\text {to }}$ Heat transfer coefficient from top glass cover to ambient, $\mathrm{W} / \mathrm{m}^{2} \mathrm{~K}$

$h_{T} \quad$ Heat transfer coefficient from back of tedlar to flowing air, $\mathrm{W} / \mathrm{m}^{2} \mathrm{~K}$

$h_{b, \text { in }}$ Heat transfer coefficient from back of insulation to ambient, $\mathrm{W} / \mathrm{m}^{2} \mathrm{~K}$

$U_{\text {tca }}$ An overall heat transfer coefficient from solar cell to ambient through glass cover, $\mathrm{W} / \mathrm{m}^{2} \mathrm{~K}$

$U_{t c f}$ An overall heat transfer coefficient from solar cell to flowing air through tedlar, $\mathrm{W} / \mathrm{m}^{2} \mathrm{~K}$

$U_{b}$ An overall back loss heat transfer coefficient from flowing air to ambient, $\mathrm{W} / \mathrm{m}^{2} \mathrm{~K}$

$I(t)$ Incident solar intensity, $\mathrm{W} / \mathrm{m}^{2}$

K Thermal conductivity, W/m K

L Length, $\mathrm{m}$

$\mathrm{N}$ Number of micro-channel solar cell thermal (MCSCT) tile

$m_{f}$ Air mass flow rate in micro-channel, $\mathrm{kg} / \mathrm{s}$

$\dot{\mathrm{Q}}_{\mathrm{u}} \quad$ Useful heat, W

$\mathrm{T}$ Temperature, $\mathrm{K}$

$\overline{\mathrm{T}} \quad$ Average temperature, $\mathrm{K}$

$U$ Overall heat transfer coefficient, $\mathrm{W} / \mathrm{m}^{2} \mathrm{~K}$

$\mathrm{v} \quad$ Velocity of air, $\mathrm{m} / \mathrm{s}$

$\eta_{o} \quad$ Efficiency at standard test condition $\left(\mathrm{I}(\mathrm{t})=1000 \mathrm{~W} / \mathrm{m}^{2}\right.$ and $\left.\mathrm{T}_{\mathrm{a}}=25^{\circ} \mathrm{C}\right)$

$\mathrm{V}$ Velocity of fluid (air) flowing inside of channel, $\mathrm{m} / \mathrm{s}$

$n_{p v} \quad$ Number of rows of micro-channel solar cell thermal (MCSCT) tile.

\begin{tabular}{ll}
\multicolumn{2}{c}{ Greek letters } \\
$\alpha$ & Absorptivity \\
$\beta$ & Packing factor \\
$\tau$ & Transmittivity \\
$\eta$ & Efficiency \\
$\rho$ & Density, $\mathrm{kg} / \mathrm{m}^{3}$ \\
Subscripts \\
a & Ambient \\
$\mathrm{c}$ & Solar cell \\
eff & Effective
\end{tabular}




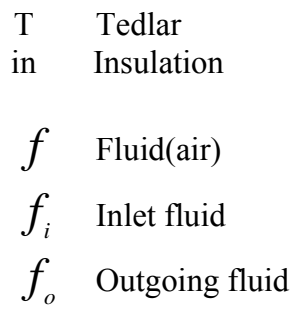

\section{Appendix}

In modeling equations, we used following relations for defining the design parameters, which are shown in Table 1 micro-channel solar cell thermal (MCSCT) tile:

$$
\begin{aligned}
& \alpha_{\text {eff }}=\tau_{g}\left(\alpha_{c}-\eta_{c}\right) \\
& h_{T}=2.8+3 \times V \\
& h_{t o}=5.7+3.8 \times v \\
& h_{b, \text { in }}=2.8+3 \times v \\
& U_{t c a}=\left(\frac{L_{g}}{K_{g}}+\frac{1}{h_{t o}}\right)^{-1} \\
& U_{t c f}=\left(\frac{L_{T}}{K_{T}}+\frac{1}{h_{T}}\right)^{-1} \\
& U_{L}=U_{b}+U_{f a}
\end{aligned}
$$

\section{References}

Agrawal S. and Tiwari, G.N., 2011. Energy and exergy analysis of hybrid micro-channel photovoltaic thermal module, Solar Energy, Vol. 85, pp. 356-370.

Bhargava AK, Garg HP, Agarwall RK. 1991. Study of a hybrid solar system-solar air heater combined with solar cells. Energy Conversion and Management, Vol. 31, No. 5, pp. 471-479.

Cox III C.H., Raghuraman P. 1985. Design considerations for flat-plate photovoltaic/ thermal collectors. Solar Energy, Vol. 35, pp. 227-241.

Chow T.T., Hand J.W., Strachan P.A. 2003. Building-integrated photovoltaic and thermal applications in a subtropical hotel building. Applied Thermal Engineering Vol. 23, pp. 2035-2049.

Chow T. T., 2010. A review on photovoltaic/thermal hybrid solar technology, Applied Energy, Vol. 87, pp. 365-369.

Chow TT, Chan ALS, Fong KF, Lin Z, He W, Ji J. 2009. Energy and exergy analysis of Photovoltaic thermal collector with and without glass cover. Appl Energy, Vol. 86, No. 3, pp. 310-316.

Dubey S, Sandhu GS, Tiwari G.N. 2009. Analytical expression for electrical efficiencyof PV/T hybrid air collector. Applied Energy, Vol. 86, No. 5, pp. 697-705.

Duffie JA, Beckman WA. Solar Engineering of Thermal Processes. John Wiley and Sons, New York, 1991.

Erdil E, Ilkan M, Egelioglu F. 2008. An experimental study on energy generation with a photovoltaic (PV)- solar thermal hybrid system. Energy, Vol. 33, pp. 1241-1245.

Evans DL. 1981. Simplified method for predicting PV array output, Solar Energy, Vol. 27, pp. 555-560.

Garg HP, Agarwall RK, Joshi JC. 1994. Experimental study on a hybrid photovoltaic thermal solar water heater and its performance prediction. Energy Conversion and Management, Vol. 35, pp. 621-633.

Garg HP, Adhikari RS. 1997. Conventional hybrid photovoltaic/ thermal (PV/T) air heating collectors: Steady-state simulation. Renewable Energy, Vol. 11, pp. 363-385.

Hegazy AA. 2000. Comparative study of the performances of four photovoltaic/ thermal solar air collectors. Energy Conversion and Management, Vol. 41, pp. 861-881.

Huang B.J., Lin T.H., Hung W.C., Sun F.S., 2001. Performance evaluation of solar photovoltaic/thermal systems, Solar Energy, Vol. 70, No. 5, pp. 443-448.

Kalogirou SA. 2001. Use of TRYNSYS for modelling and simulation of a hybrid PV thermal solar system for Cyprus. Renewable Energy, Vol. 23, pp. 247- 260. 
Kern Jr. EC, Russell MC. 1978. Combined photovoltaic and thermal hybrid collector systems. In: Proc. 13th IEEE Photovoltaic Specialists, Washington DC, USA, pp. 1153-1157.

Lee WM, Infield DG, Gottschalg R. 2001. Thermal modelling of building integrated PV systems In: Proceedings of 17th PV Solar Energy Conference. Munich, 22-26 October, pp. 2754-2757.

Nayak S., Tiwari G.N.,.2008. Energy and Exergy analysis of photovoltaic/thermal integrated with a solar greenhouse, Energy and Buildings, Vol. 40, pp. 2015-2021.

Prakash, J. 1994. Transient analysis of a photovoltaic-thermal solar collector for co-generation of electricity and hot air/water. Energy Conversion and Management, Vol. 35, pp. 967-972.

Radziemska E., 2009 Performance analysis of a photovoltaic-thermal integrated system, Int. Journal of Photoenergy, pp. 1-6.

Sopian K, Liu HT, Kakac S, Veziroglu TN. 2000. Performance of a double pass photovoltaic thermal solar collector suitable for solar drying systems. Energy Conversion and Management, Vol. 41, No. 4, pp. 353-365.

Schott T. 1985. Operational temperatures of PV modules. In: Proceedings of $6^{\text {th }}$ PV Solar Energy Conference, pp. $392-396$.

Tiwari A, Sodha MS, Chandra A, Joshi JC. 2006. Performance evaluation of photovoltaic thermal solar air collector for composite climate of India. Solar Energy Materials and Solar Cells, Vol. 90, No. 2, pp. 175-189.

Tiwari A, Dubey S, Sandhu G.S., Sodha M.S., Anwar S.I., 2009. Exergy analysis of integrated photovoltaic thermal solar water heater under constant flow rate and constant collection temperature modes, Vol. 86, pp. 2592-2597..

Tiwari A, Sodha MS. 2006. Performance evaluation of solar PV/T system: An experimental validation. Solar Energy, Vol. 80, No. 7, pp. 751-759.

Tiwari GN. 2004. Solar Energy: Fundamentals, Design, Modeling and Applications. Narosa Publishing House, New Delhi.

Zondag, H.A., de Vries, D.W. de, van Helden, W.G.J. ,van Zolengen, R.J.C. and steenhoven, A.A., 2002. The thermal and electrical yield of a PV-thermal collector. Solar Energy, Vol. 72, No. 2, pp. 113-128.

\section{Biographical notes}

Sanjay Agrawal received B. E. from Madan Mohan Malviya engineering college, Gorakhpur, UP, India, M.Tech from U.P. technical university, Lucknow, UP, India and presently pursuing Ph.D. from Indian Institute of Technology Delhi, India. He is a Reader in the Department of electrical and electronics engineering, G.L.A. university, Mathura, India. Presently he is on leave from G.L.A. University, Mathura His areas of research interest are solar thermal, photovoltaics, heat and mass transfer, exergy, $\mathrm{CO}_{2}$ mitigation, climate change and carbon trading. He is a Graduate memeber of IE (India).

Dr. G.N. Tiwari received postgraduate and doctoral degrees in 1972 and 1976, respectively, from Banaras Hindu University (B.H.U.) He is a Professor in the centre for energy studies, Indianl Institute of Technology Delhi, India. He has more than 35 years of experience in teaching and research. His research interest in the field of Solar Energy Applications are solar distillation, water/air heating system, greenhouse technology for agriculture as well as for aquaculture, Earth to air heat exchanger, passive building design and hybrid photovoltaic thermal (HPVT) systems, climate change, energy security, etc. He has guided about 55 Ph.D. students and published over 450 research papers in journals of repute. He has authored twenty books associated with reputed publishers. He is a co-recipient of 'Hariom Ashram Prerit S.S. Bhatnagar' Award in 1982. Professor Tiwari has been recognized both at national and international levels. Dr. Tiwari was Editor of International Journal of Agricultural Engineering for the duration of three years (2006-2008). He is Associate Editor for Solar Energy Journal (SEJ) in the area of Solar Distillation since 2007. He. He is also Editor of International Journal of Energy Research. Prof. G.N.Tiwari has been conferred "Vigyan Ratna" by Govt. of U.P., India on March 26, 2008 and Valued Associated Editor award by J. of Solar Energy. He has organized SOLARIS 2007, third international conference on "Solar Radiation and Day lighting" held at IIT Delhi, New Delhi, India from February 7 to 9, 2007. He is also president of Bag Energy Research Society (BERS:www.bers.in) which is responsible for energy education in rural India. His current area of research includes Multi-criteria Decision-Making, Quality Engineering, Assembly Line Balancing, Group Technology, Neural Networks, and Non-traditional Optimization and Simulation. He has published more than fifty papers in referred international journals. He has also presented more than one hundred research articles in national and international conferences. He has written few books related to his research work. He is currently dealing with few projects sponsored by government of India.

Received January 2011

Accepted March 2011

Final acceptance in revised form May 2011 